\title{
Urządzenie UKS do kontroli szczelności złączy spawanych w próbie pęcherzykowej z przyssawką próżniową
}

\section{The UKS device with a vacuum cup for leak testing of welded joints using a bubble test}

\section{Streszczenie}

W artykule przedstawiono pęcherzykową próbę badania szczelności i urządzenie UKS umożliwiające jej realizację w wersji z przyssawką próżniową. Omówiono konstrukcję i zakres zastosowania komór próżniowych oraz podano ustalone warunki kontroli szczelności. Urządzenie UKS spełnia wymagania norm PN-EN 1779 i PN-EN 1593. Ponadto zostało wyróżnione złotymi medalami na prestiżowych międzynarodowych imprezach targowych.

Słowa kluczowe: badania nieniszczące, szczelność

\section{Abstract}

The article presents a bubble leak testing and an UKS device designed for this method of testing using a vacuum cup. Vacuum chambers design and application range is discussed as well as the established conditions for leak testing are given. The UKS device meets the requirements of PN-EN 1779 and PN-EN 1593 standards. It has been awarded gold medals of prestigious international fairs.

Key words: non-destructive welding, leak testing

\section{Wstęp}

Badania szczelności stanowia liczna grupe metod badawczych umożliwiających wykrywanie nieciągłości materiałowych na wskroś kontrolowanego obiektu, czyli jego nieszczelności. Spośród tych metod coraz szersze zastosowanie do badania szczelności złączy spawanych znajduje próba pęcherzykowa z przyssawką próżniową. $Z$ tego powodu opracowano urządzenie, którego wykorzystanie umożliwia łatwe zastosowanie metody w praktyce przemysłowej $[1,2]$.

\section{Charakterystyka metody}

Badanie szczelności w próbie pęcherzykowej z przyssawką próżniową oparte jest na zjawisku przenikania gazu z ośrodka o ciśnieniu wyższym do drugiego o ciśnieniu niższym, gdy istnieje połączenie między

nimi. Badanie złączy odbywa się w powietrzu atmosferycznym, przy wytworzonym podciśnieniu w komorze nałożonej na badany odcinek złącza (rys. 1).

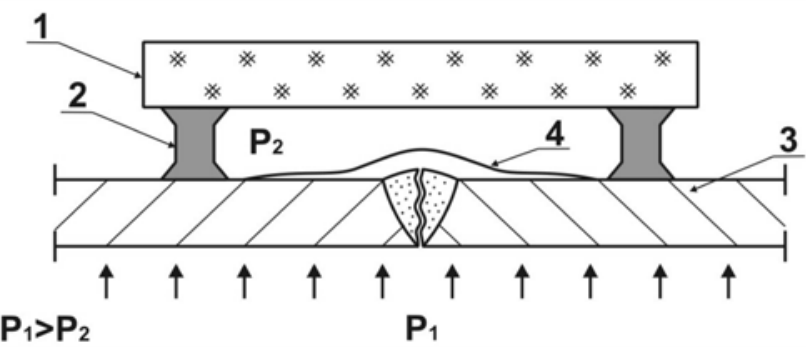

Rys. 1. Zasada badania szczelności złączy spawanych za pomocą próby pęcherzykowej z przyssawką próżniową: 1 - przezroczysta płyta obserwacyjna, 2 - pierścień uszczelniający, 3 - złącze spawane z nieszczelnością, 4 - pęcherz ujawniający nieszczelność

Fig. 1. Principle of testing of welded joints leaktightness by bubble test with vacuum cup: 1 - transparent observation plate, 2 - sealing ring, 3 - welded joint with leakage, 4 - bubble revealing leakage

Mgr inż. Janusz Czuchryj, mgr inż. Adam Pilarczyk - Instytut Spawalnictwa w Gliwicach. Autor korespondencyjny/Corresponding author: janusz.czuchryj@is.gliwice.pl 
Nieszczelność w złączu stanowi połączenie między ośrodkami o różnym ciśnieniu. W wyniku oddziaływania różnicy ciśnień następuje przenikanie powietrza z atmosfery do komory przez nieszczelność. Powoduje to powstanie pęcherza w roztworze pianotwórczym, którym pokryte jest złącze, i zlokalizowanie w ten sposób występującej w nim wady ułożonej na wskroś.

Należy jednak zauważyć, że metoda pęcherzykowa z przyssawką próżniową nie zastępuje ciśnieniowej próby szczelności lub wytrzymałości konstrukcji.

\section{Urządzenie UKS}

Do kontroli szczelności złączy spawanych za pomocą próby pęcherzykowej z przyssawką próżniową zaprojektowano i zbudowano w Instytucie Spawalnictwa

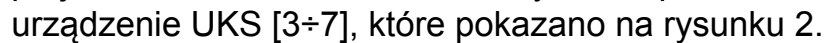

Urządzenie składa się z komór próżniowych (podłużnych i okrągłej) oraz pompy ssącej. Komory próżniowe ograniczają przestrzeń, w której wytwarzane jest podciśnienie robocze.

Komory zbudowane są z przezroczystych płyt obserwacyjnych, ścianek bocznych ograniczających komory na obwodzie i uszczelek gumowych. Przezroczyste płyty umożliwiają obserwację badanego odcinka złącza podczas procesu kontroli, natomiast uszczelki ściśle przylegające do złączy izolują objętość komór od otoczenia. W płytę obserwacyjną każdej komory wbudowano łącznik do elastycznego przewodu oraz zawór zapowietrzający. Zawór umożliwia zapowietrzenie komory po przeprowadzeniu kontroli, jak również regulację w niej ciśnienia przez odpowiednie ustawienie pokrętła. Pompa ssąca wytwarza w komorze

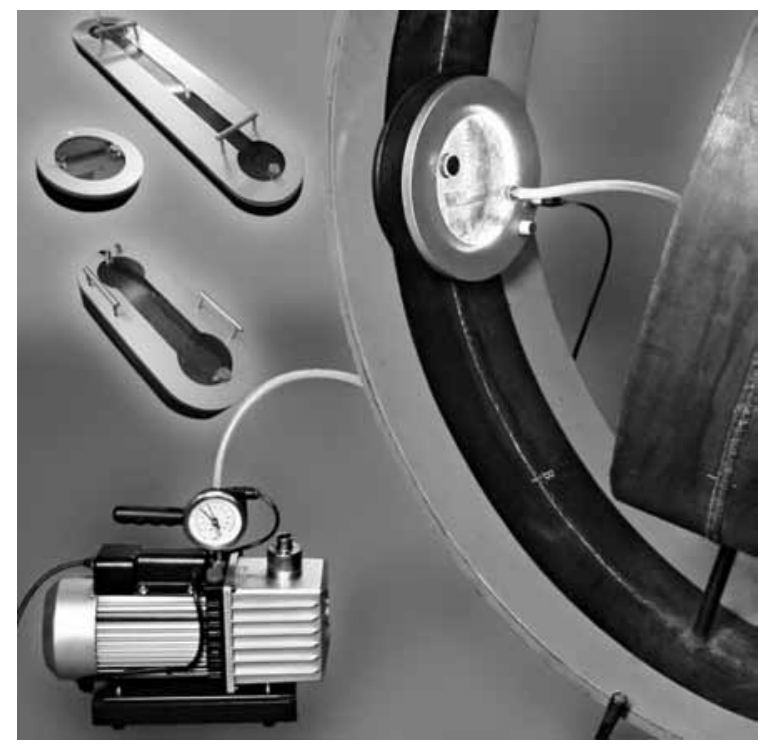

Rys. 2. Urządzenie UKS do kontroli szczelności złączy spawanych za pomocą próby pęcherzykowej z przyssawką próżniową

Fig. 2. The UKS device for inspection of leaktightness of welded joints by means of bubble test with vacuum cup wymagane podciśnienie przez wypompowanie z niej powietrza przez elastyczny przewód łączący komorę z pompą. Aby zapewnić właściwe warunki obserwacji tworzących się pęcherzy, komory wyposażono w diodowe oświetlenie o regulowanym natężeniu. Umożliwia to przeprowadzenie kontroli w dowolnych warunkach oświetlenia środowiska pracy operatora. Komory podłużne są przeznaczone do kontroli płaskich złączy doczołowych. Komora okrągła służy do badania złączy doczołowych krzyżujących się oraz złączy na powierzchniach zakrzywionych (np. sferycznych) (rys. 3). a)

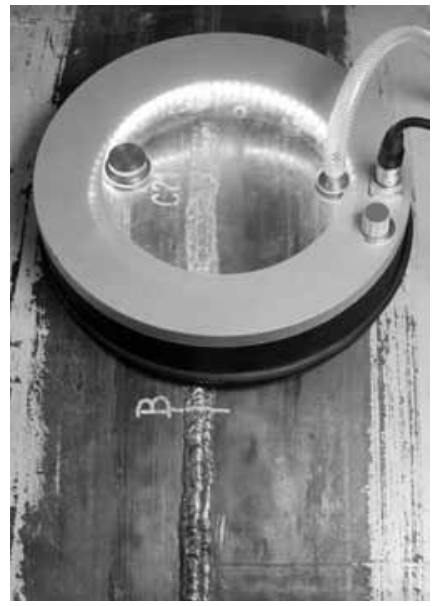

b)

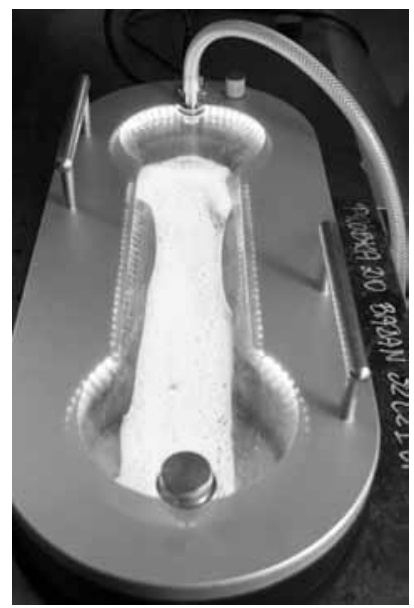

Rys. 3. Kontrola szczelności złączy spawanych za pomocą: a) komory podłużnej, b) komory okrągłej

Fig. 3. Inspection of leaktightness of welded joints by means of: a) longitudinal chamber, b) circular chamber

Kontrola złączy płaskich za pomocą komory okrągłej jest również możliwa. Wynika to stąd, że komora okrągła charakteryzuje się dużą uniwersalnością. Jednak podczas badania złączy płaskich komory podłużne charakteryzują się dużo większą wydajnością. Zarówno konstrukcje komór podłużnych, jak i konstrukcja komory okrągłej umożliwiają kontrolę szczelności spoin pachwinowych w złączach zakładkowych (nakładkowych), przy czym grubość materiału podstawowego nie powinna być większa niż $10 \div 12 \mathrm{~mm}$.

Wysokość nadlewu kontrolowanych spoin czołowych nie powinna przekraczać wartości 1,5 $\div 2,0 \mathrm{~mm}$. Lico spoin czołowych powinno łagodnie przechodzić do materiału podstawowego. Lico spoin pachwinowych powinno być płaskie lub lekko wklęsłe i łagodnie przechodzić do materiału podstawowego. W odniesieniu do spoin otworowych specjalnych wymagań nie ustala się. Przed badaniem spoinę oraz przylegającą do niej z obu stron strefę o szerokości co najmniej $40 \mathrm{~mm}$ należy dokładnie oczyścić z rdzy, farby, smarów, żużla, zgorzeliny i rozprysków stopiwa elektrod.

Warunki kontroli ustalono dla roztworu pianotwórczego, jaki stanowi woda z mydłem i gliceryną. Warunki kontroli to: zastosowana różnica ciśnień, czas jej utrzymania, temperatura badanej powierzchni i temperatura roztworu pianotwórczego. Różnica pomiędzy ciśnieniem powietrza atmosferycznego, a powietrzem 
w komorze (wartość podciśnienia) nie może być mniejsza niż $50 \mathrm{kPa}$. Czas utrzymania różnicy ciśnień powinien wynosić co najmniej $30 \mathrm{~s}$. Temperatura badanej powierzchni powinna być w zakresie $5 \div 50^{\circ} \mathrm{C}$, a temperatura roztworu w zakresie $15 \div 30^{\circ} \mathrm{C}$.

Kontrola szczelności urządzeniem UKS polega na nałożeniu komory próżniowej na badaną powierzchnię (np. złącza), jej dociśnięciu, wypompowaniu powietrza i obserwacji tworzenia się pęcherzy (rys. 4).

W miejscu powstania pęcherza (pęcherzy) znajduje się nieszczelność. Następnie komorę zapowietrza się, nakłada na kolejny odcinek powierzchni i powtarza opisane czynności. Wyniki kontroli szczelności powinny być ujęte $w$ formie sprawozdania $z$ badania. Natężenie przepływu, jakie można wykrywać przy użyciu komór próżniowych, wynosi ok. $5 \cdot 10^{-5} \mathrm{~Pa} \cdot \mathrm{m}^{3} / \mathrm{s}$ [1].

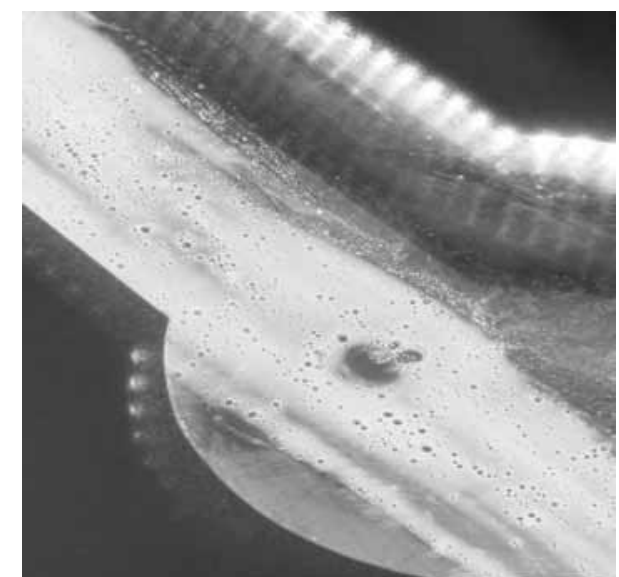

Rys. 4. Tworzenie się pęcherzy identyfikujących nieszczelność na powierzchni badanego złącza spawanego

Fig. 4. Formation of bubbles identifying a leakage on the surface of test welded joint
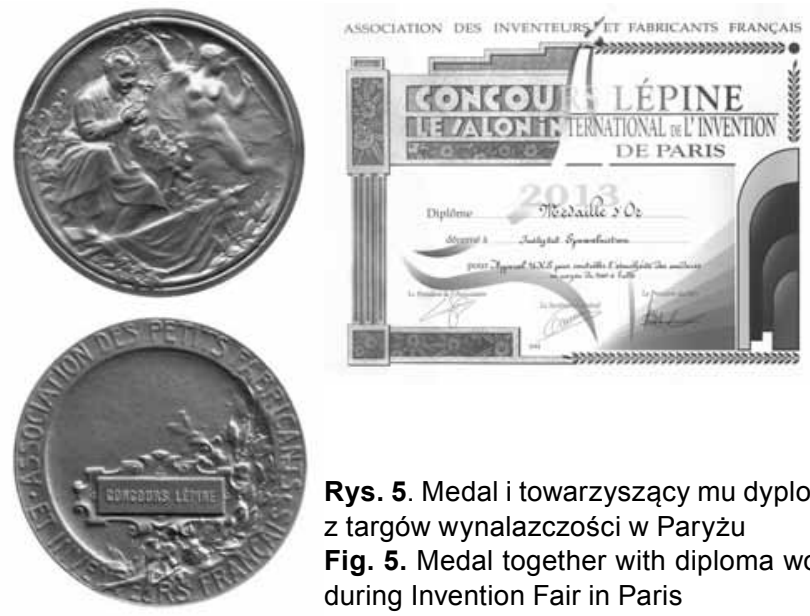

Rys. 5. Medal i towarzyszacy mu dyplom z targów wynalazczości w Paryżu Fig. 5. Medal together with diploma won during Invention Fair in Paris
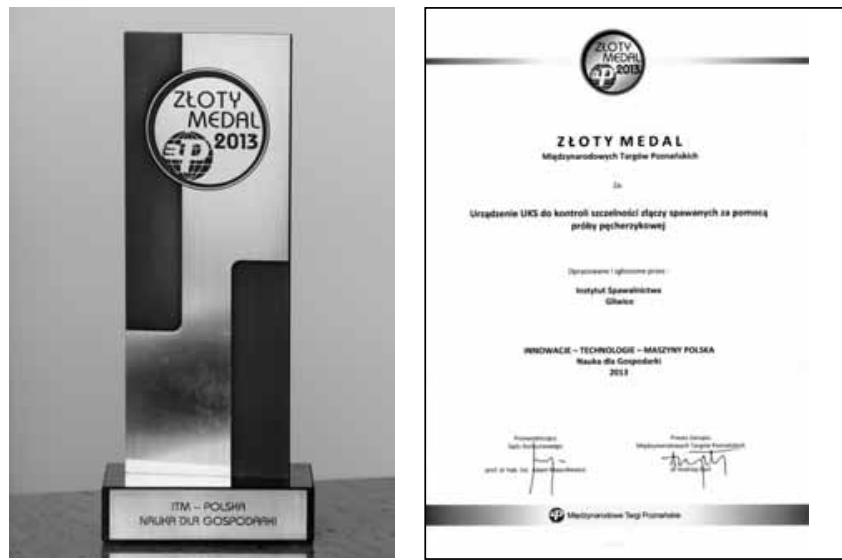

Rys. 6. Medal wraz z dyplomem z Międzynarodowych Targów Poznańskich

Fig. 6. Medal together with diploma won during International Poznań Fair

\section{Podsumowanie}

Rozwiązanie konstrukcyjne opisanego urządzenia znalazło uznanie Urzędu Patentowego Rzeczpospolitej Polskiej. Decyzją nr DT/Wp.20509/6/EDO z dnia 12.03.2013 r. udzielono Instytutowi Spawalnictwa w Gliwicach „PRAWA Z REJESTRACJI” wzoru przemysłowego pt. „Urządzenie do kontroli szczelności złączy spawanych za pomocą próby pęcherzykowej z komorą próżniową".

Urządzenie UKS poddano krytycznej ocenie na targach wynalazczości, które odbyły się w Paryżu w maju 2013 r. W wyniku tej oceny urządzenie wyróżniono złotym medalem (rys. 5). Przyznano mu również wyróżnienie złotym medalem na Międzynarodowych Targach Poznańskich w czerwcu 2013 r. (rys. 6).
Zaprojektowane i zbudowane urządzenie UKS do kontroli szczelności złączy spawanych (i innych powierzchni) za pomocą próby pęcherzykowej z przyssawką (komorą) próżniową wypełniło pewną lukę w zakresie zastosowania różnych metod badania szczelności. Umożliwia to szersze wykorzystanie metody pęcherzykowej w praktyce przemysłowej, w szczególności w odniesieniu do tych wyrobów, w których podstawowym warunkiem dopuszczenia do eksploatacji jest szczelność wykonanych połączeń spawanych (np. zbiorników bezciśnieniowych na gazy i ciecze, silosów, cystern, bezciśnieniowych rurociągów, den zbiorników magazynowych itp.). 


\section{Literatura}

[1] Hlebowicz J.: Badanie szczelności. Poradnik. Wydawnictwo „Biuro Gamma”. Warszawa, 1996

[2] Hlebowicz J.: Badania nieniszczące. Badanie szczelności urządzeń i instalacji technicznych. Poradnik. Wydawnictwo „Biuro Gamma”. Warszawa, 2001.

[3] Czuchryj J.: Urządzenie do kontroli szczelności złączy spawanych metodą próżniową. Prace Instytutu Spawalnictwa nr 4, 1982.

[4] Czuchryj J.: Urządzenie do kontroli szczelności metodą próżniową połączeń spawanych. Przegląd Spawalnictwa nr 1, 1984.

[5] Czuchryj J.: Urządzenie UKS - 2 do kontroli szczelności złączy spawanych metodą podciśnieniową. Biuletyn Instytutu Spawalnictwa $\mathrm{nr} 4,1993$.

[6] Czuchryj J.: Wykorzystanie metody podciśnieniowej do kontroli szczelności złączy spawanych. Biuletyn Instytutu Spawalnictwa $\mathrm{nr}$ 6, 1999.

[7] Czuchryj J., Bartosz Ł.: Zastosowanie próby pęcherzykowej do badania szczelności złączy spawanych. Biuletyn Instytutu Spawalnictwa nr 6, 2006.

[8] Czuchryj J., Robakowski T.: Kontrola w spawalnictwie. SIMP. Śląski Ośrodek Doskonalenia Kadr w Gliwicach. Materiały szkoleniowe. Gliwice, 1985.
[9] Czuchryj J., Stachurski M.: Badania nieniszczące w spawalnictwie. Wydawnictwo Instytutu Spawalnictwa. Gliwice, 2002.

[10] Czuchryj J.: Kontrola szczelności złączy spawanych za pomocą próby pęcherzykowej z przyssawką próżniową. Wytyczne Instytutu Spawalnictwa nr W - 12/IS - 57.

[11] Szymański A.: Kontrola i zapewnienie jakości w spawalnictwie. Tom 2. Wydawnictwo Politechniki Śląskiej. Gliwice, 1998.

\section{Normy}

- PN-EN 1330-8 Badania nieniszczące - Terminologia - Terminy stosowane $w$ badaniach szczelności.

- PN-EN 1593 Badania nieniszczące - Badania szczelności - Próba pęcherzykowa.

- PN-EN 1779 Badania nieniszczące - Badania szczelności - Kryteria wyboru metody i techniki.

- PN-EN ISO 9712 Badania nieniszczące - Kwalifikacja i certyfikacja personelu badań nieniszczących.

\section{Odczyty techniczne}

\section{Organizowane przez Sekcję Spawalniczą OW SIMP w I kwartale 2014 roku, dostępne dla członków SIMP, NOT oraz wszystkich sympatyków spawalnictwa.}

\begin{tabular}{|c|c|}
\hline \multicolumn{2}{|c|}{ Wydział Inżynierii Produkcji Politechniki Warszawskiej } \\
Gmach Nowy Technologiczny \\
Warszawa, ul. Narbutta 85, sala NT 129 \\
Dojazd tramwajami: 17 i 33
\end{tabular}

